\title{
The Philosophy and Authentication of Welfare Equalization in the Islamic Economy
}

\author{
Aang Kunaifi ${ }^{1}$, Fadali Rahman ${ }^{2}$, Risca Dwiaryanti² \\ 1Ph.D Sharia Economics of State Islamic University of Sunan Ampel Surabaya, Lecturer at Islamic Institute of Al-Khairat, Pamekasan, \\ Indonesia \\ ${ }^{2}$ Faculty of Islamic Economic and Business, Islamic Institute of Al-Khairat, Pamekasan, Indonesia
}

\section{ARTICLE INFO \\ ABSTRACT}

\section{Keywords}

Philosophy, Authentication,

Welfare, Islamic Economics

\section{*Correspondence}

akunaifi@gmail.com

\section{Article History}

Received 27 January 2021

Accepted 24 June 2021

Published on-line 25 June 2021

\begin{abstract}
The promise of the welfare of the capitalist economic system initiated three centuries ago is only realized for the owners of capital. Even in 2017 in The Great Devide, Joseph E. Stigliz reported increasingly alarming data that the wealth of $1 \%$ of the world's population is equivalent to $99 \%$ of the world's population. This article aims to describe: (1) The concept and philosophical value of welfare in Islam, and (2) historical authentic evidence of the creation of welfare in Islam. To obtain representative and comprehensive data, this article is compiled based on primary and secondary data. The Central Bureau of Statistics reports economic developments regarding the development of people's welfare in Indonesia and reports from world institutions such as the IMF, World Bank, as a comparison of global economic conditions. The data is then discussed under ideal conditions recorded in the golden history of Islam to find that prosperity in an Islamic economy is capable of being realized. The contribution of articles among scientific studies that discuss welfare is about concrete explanations or clear standards of welfare attainment. Namely, the nominal wealth to be called prosperous, an applicative and systematic method of achievement, and the affirmation that the Islamic economic system has proven to be effective in creating prosperity. Through the presentation of this article, it is hoped that efforts to create prosperity as well as equalize welfare will always be pursued through the application and contextualization of a proven and tested economic system.
\end{abstract}

\section{INTRODUCTION}

The current turmoil of economic condition in the world has made the leaders of some countries busy looking for solutions to stop the bleeding due to their fatal financial-economic accidents. Countries that mainly implement an economic system of capitalism based on usury and gambling are trying to maintain this fragile system by doing patchwork. Various crisis rescue packages have been prepared to cover the depravity of their system with trillions of dollars. However, when a wreck was covered up, other ulcers appeared. As a result, we can witness the economic and financial crises that continue to plague capitalist countries.

Roy Davies and Glyn Davies reveal historical facts in 1996 in their book entitled The History of Money from Ancient Times to Present Day. At least during the 20th century, there have been 20 significant crises that hit many countries. This means that the financial crisis occurs every 5 years, which causes suffering for hundreds of millions of people (Davies, 2010). The great crisis and crash were recorded to hit the New York capital market and the great depression due to banking failures. Still fresh in our memories in 2010, a crisis hit the world again, in Europe mainly as the countries champion capitalism. Greece, Spain, France, Germany, and America could not escape from the financial and banking crisis outbreak, which was quite terrible. The impact was quite devastating. Let's say that one of the oldest and largest investment banks with 158 years of age, Lehman Brothers, was declared bankrupt. Several giant companies such as Merril Linch, Chrysler, Goldman Sachs Group, and Xerox Corp were forced to lay off thousands and even tens of thousands of employees (Mansur, 2013). All show that the capitalist economic system based on usury and gambling economies is not worth defending.

As a new economic power globally with achievement of $9 \%$ growth per year, China can reduce its 400 million inhabitants. This is only a temporary situation in removing the fact that poverty is still high among billions of people, especially those living in rural areas (Zakaria, 2011). China by maneuvering its economic system from socialist to capitalist only to enjoy the euphoria of development minus the equal distribution of welfare that its people expect.

(C) 2021 by the authors; licensee PRIMA, Hannover, Germany. This is an Open Access article distributed under the terms of the Creative Commons Attribution-ShareAlike 4.0 International License. (https://creativecommons.org/licenses/by-sa/4.0/), which permits unrestricted use, distribution, and reproduction in any medium, provided the original work is properly cited. 
Table 1. World gini coeficient

\begin{tabular}{ll}
\hline Country & Coeficient Gini (2018) \\
\hline Union of Eropa: & \\
Republik Slovakia & 0.235 \\
Denmark & 0.264 \\
Finlandia & 0.269 \\
Swedia & 0.275 \\
Belanda & 0.285 \\
Perancis & 0.301 \\
Spanyol & 0.330 \\
Lithuania & 0.361 \\
Bulgaria & 0.408 \\
United Kingdom & 0.336 \\
Indonesia & 0.380 \\
United States & 0.390 \\
Mexico & 0.458 \\
China & 0.465 (2019) \\
\hline \multicolumn{2}{c}{ Adapted from OECD.org }
\end{tabular}

From the same source, OECD.org, as shown in Tabel 1, it was noted that the poverty rate of countries in the world in 2018 ranged from $5-27 \%$ of the country's population. Denmark occupies the lowest percentage rate, namely $4.7 \%$, and the highest poverty rate in Costa Rica at 19\% in 2019. Even over a period of 66 years, Korea recorded an average poverty rate of up to $43.4 \%$ ("Inequality - Income Inequality - OECD Data," t.t.). All of those countries have been applying capitalism.

The Central Statistics Agency (BPS) noted that the poverty rate in Indonesia as of March 2020 had increas ed to 26.42 million people. With this position, the percentage of poor people in March 2020 also rose to 9.78 percent ("Badan Pusat Statistik," t.t.). Thus, economic disparities are increasingly far from safe. With a Gini of $0.38-0.42$, it is not easy to expect a trickle-down effect that hopes to create prosperity. Therefore, through this article, the author tries to explain how the value of the philosophy of welfare and its authenticity is based on an Islamic economic perspective.

Studies on welfare have been widely discussed in various studies, among others; (Nasim, 2018). This article discusses the facts of the failure of the capitalist economic system in creating welfare due to errors in understanding scarcity while at the same time emphasizing the ability of the Islamic economic system to be able to provide welfare through adequate sources of state income. There is also research on the effectiveness of the Islamic economic system, which can create growth through a systematic distribution method, not only growth-oriented (Darussalam, Adilah, Berlian, \& Danial, 2019). Another research explains that welfare in Islam has its dimensions. First, welfare is not seen in terms of material only, but also in terms of peace of mind, heart and mind of a person, and the concept of reward (immaterial)(Darussalam et al., 2019). The conceptual value of well-being in Islam is also discussed in the following article (Rochman, 2020) and also (Suardi, 2021).

Table 2. Literature review on wealth of islamic economic perspectives

\begin{tabular}{|c|c|c|c|c|c|}
\hline No & $\begin{array}{l}\text { Researcher, } \\
\text { Year }\end{array}$ & Title & Aims & Method & Findings \\
\hline 1 & $\begin{array}{l}\text { Arim Nasim, } \\
2018\end{array}$ & $\begin{array}{l}\text { Sistem dan Politik } \\
\text { Ekonomi Islam dalam } \\
\text { Mewujudkan } \\
\text { Kesejahteraan }\end{array}$ & $\begin{array}{l}\text { Describes } \\
\text { capitalism fault } \\
\text { and explain } \\
\text { Islamic } \\
\text { economics as an } \\
\text { alternative }\end{array}$ & $\begin{array}{l}\text { Qualitative, } \\
\text { Critical } \\
\text { Theory } \\
\text { Approach }\end{array}$ & $\begin{array}{l}\text { The fault of capitalism is caused by } \\
\text { liberalism in ownership and } \\
\text { distribution. Islam has a } \\
\text { comprehensive namely personal } \\
\text { ethic and state enforcement. }\end{array}$ \\
\hline 2 & $\begin{array}{l}\text { Darussalam et } \\
\text { al., } 2019\end{array}$ & $\begin{array}{l}\text { Konsep Pertumbuhan } \\
\text { Ekonomi Dan } \\
\text { Kesejahteraan Dalam } \\
\text { Islam }\end{array}$ & $\begin{array}{l}\text { Explore and } \\
\text { explain the } \\
\text { economic wealth } \\
\text { and growth from } \\
\text { an Islamic } \\
\text { perspective }\end{array}$ & $\begin{array}{l}\text { Qualitative, } \\
\text { library, and } \\
\text { literature } \\
\text { review } \\
\text { approach }\end{array}$ & $\begin{array}{l}\text { Conclude that wealth in Islam not } \\
\text { just measure by material but also } \\
\text { immaterial value as peace of mind }\end{array}$ \\
\hline 3 & $\begin{array}{l}\text { T. Rochman, } \\
2020\end{array}$ & $\begin{array}{l}\text { Nilai Nilai Instrumental } \\
\text { Ekonomi Islam dalam } \\
\text { Kesejahteraan } \\
\text { masyarakat ditengah } \\
\text { Covid } 19\end{array}$ & $\begin{array}{l}\text { Explore the } \\
\text { instrument and } \\
\text { value of the } \\
\text { Islamic spirit to } \\
\text { solve the covid- } \\
19 \text { outbreak }\end{array}$ & $\begin{array}{l}\text { Qualitative, } \\
\text { phenomenon } \\
\text { approach }\end{array}$ & $\begin{array}{l}\text { Individual spiritual is essential to } \\
\text { facing a pandemic and found the } \\
\text { miracle or hikmah }\end{array}$ \\
\hline 4 & $\begin{array}{l}\text { Didi Suardi, } \\
2021\end{array}$ & $\begin{array}{l}\text { Makna Kesejahteraan } \\
\text { Dalam Sudut Pandang } \\
\text { Ekonomi Islam }\end{array}$ & $\begin{array}{l}\text { Explain the } \\
\text { wealth according } \\
\text { to Islamic Law }\end{array}$ & $\begin{array}{l}\text { Literature } \\
\text { review/ } \\
\text { library } \\
\text { research }\end{array}$ & $\begin{array}{l}\text { Welfare standard in Islamic is } \\
\text { covering material and spiritual or } \\
\text { maqashidu al-sharia }\end{array}$ \\
\hline
\end{tabular}

As described in Table 2, research on welfare issues and the concept of realizing welfare is always exciting and essential to discuss. Various propositions of concepts and ideas in realizing welfare need to be accommodated in order to find the most effective solution. Therefore, the concept that has been offered needs to be contextualized following the dynamics of social and economic change. In essence, an updated concept is needed to make the concept more applicable. The novelty and position of this article can be explained as shown in Table 3, namely as a research update and complementary findings covering the philosophical concept of welfare in Islamic economics and applicable concepts in realizing the intended welfare. 
Table 3. Research position and novelty

\begin{tabular}{|c|c|c|c|c|}
\hline Variable & Year & Method & Aims & Findings \\
\hline $\begin{array}{l}\text { The Philosophy And } \\
\text { Authentication Of } \\
\text { Equalization Of } \\
\text { Welfare In The } \\
\text { Islamic Economy }\end{array}$ & 2021 & $\begin{array}{l}\text { Literature review } \\
\text { and empirical data }\end{array}$ & $\begin{array}{l}\text { Explore and explain } \\
\text { the concept and } \\
\text { philosophical value of } \\
\text { welfare in Islam, and } \\
\text { also authentic } \\
\text { historical evidence of } \\
\text { the creation of welfare } \\
\text { in Islam }\end{array}$ & $\begin{array}{l}\text { 1. Welfare in the philosophy of Islamic } \\
\text { economics is built in the form of } \\
\text { adequate income and minimal inequality. } \\
\text { 2. Welfare in an Islamic economy is } \\
\text { manifested through production, } \\
\text { distribution, and consumption of } \\
\text { economic resources following sharia } \\
\text { 3. The form of welfare in Islamic economics } \\
\text { has been proven by Muslim and non- } \\
\text { Muslim historians }\end{array}$ \\
\hline Novelty & Yes & No & Yes & No. 1 and 2 \\
\hline
\end{tabular}

\section{RESEARCH METHODS}

This article is written based on a literature study and historical data, and current empirical data. Furthermore, it is compared to describe the philosophy and authentication of welfare in Islamic economics. The data collection and analysis were carried out qualitatively with a phenomenological approach. The comprehensive data source is secondary data obtained through books and articles on various economic problems on a local and global scale. In addition, empiric data is also collected through news and reports from various credible national and international institutions. This is felt to be sufficient to represent a picture of the economic situation of the world community, as well as being felt and assessed through observing the phenomena of life around the author, described objectively so that everyone can explain that the community is still experiencing the problem of inequality and is getting worse. Furthermore, considering that no country in the world has implemented an economic system, namely, an economic system that is regulated based on sources of Islamic law, the historical facts revealed by historians, both Muslim and non-Muslim, are a representation of the recognition of the realization of prosperity during the duration of Islamic civilization.

\section{RESULTS AND DISCUSSIONS}

\subsection{Islamic Economic Philosophy}

Philosophy can be defined as an effort to think about a phenomenon systematically and deeply according to one's abilities (Muslih, 2014). Philosophy is not just thinking about or questioning a phenomenon but also analyzed systematically, radically, and critically (Athoillah \& Q-Anees, t.t.). These thoughts will become the flow and method of formulating a problem and forming a basic framework for solving the problem. So, in essence, philosophy can be defined as a particular view to answer a problem (Tafsir, 2013).

The Islamic economy can be defined in 3 approaches, among others (Yusanto \& Yunus, 2009):

1) Islamic economics, namely economics based on Islamic value or sharia; Islamic economics in this context has implications for the inclusion of Islamic values as ethics in production activities, such as; halal raw materials, halal and hygienic process, as well as honest information about product composition. In distribution activities applied of the halal supply chain, prohibition of monopolizing, prohibition of hoarding for speculative purposes and so on. Whereas in the context of consumption, it takes a rule prohibiting tabdzir and israf, mean waste.

2) Islamic economic system, namely as a rule in economic activity in society; What is meant here is applying the economic system in positive law. The government adopts Islamic economic laws to be applied in the life of the nation and state. We are implementing a monetary and fiscal system according to sharia, applying transaction laws according to Islamic law, and resolving business disputes under Islamic law.

3) Islamic economy, which means a phenomenon or economic condition that occurs in countries with a majority Muslim population. The explanation is, for example, a discussion of the situation and economic dynamics of the people in Indonesia, Malaysia, Brunei, Arabia, Egypt, Kuwait, Turkey, and others. These countries cannot be called Islamic countries, but countries that are predominantly Muslim. So the Islamic economy can also be interpreted as economic activity in countries that are representative of the Muslim population.

Humans have universal equality in fulfilling basic or principal needs without being differentiated according to social, educational, cultural, and religious backgrounds. Humans are interested in fulfilling their physical needs, emotional needs or feelings, and spiritual needs. ${ }^{1}$ Therefore, humans share the desire to carry out economic activities, for example, producing to produce goods, managing land, raising livestock, developing capital, conducting trade, and creating various service activities other humans need to get assets or resources to meet their needs. Thus in the context of needs, humans are both faced with activities to meet their needs. So that what distinguishes is the procedures and rules used by part of society with other communities. Therefore, Islamic economics is more accurately defined by the approach of a rule and procedure in managing the economic activities of society based on sharia. Islamic economics is also an activity of producing, distributing, and consuming goods or services following the rules of halal haram, specifically Islam advocates producing or creating goods or services in order to improve economic welfare (Ilmy, 2019).

Economic philosophy, in general, is the basis of an economic system to be built, including goals, policies, and methods. Based on the description above, if the definition of philosophy, Islamic economics, and economic philosophy is integrated, Islamic economic philosophy can be interpreted as a method or point of view of Islamic teachings in analyzing and resolving economic phenomena, both in the fields of production, distribution, and consumption. The implementation of Islamic economic philosophy will appear in production, distribution, and consumption procedures as the main economic activities to solve economic problems

\footnotetext{
${ }^{1}$ Fundamentally human needs can be divided into two parts, namely physical needs and instinctive needs. Physical needs (hajatul 'udhawiyyah) are all needs that come from internal humans, such as; the need for food and drink to meet hunger and thirst, clothing and housing to protect against extreme weather, and so on. As for instinct, it is a need whose stimulus comes from externals such as; instinct to serve oneself to the Creator ( $g$ harizah al-tadayyun), instinct for self-defense or ego (gharizah al-baqa'), and instinct to preserve offspring (gharizah al-nau'). Look at (Abdurrahman, 2010 ) page 48-51.
} 
(fulfill human needs) and realize economic justice (income distribution) and welfare. Islamic economic philosophy is an economic activity based on a triangle concept, namely ilahiyah, insaniyah and kauniyah values (Rivai, Nuruddin, \& Ananda Arfa, 2012).

\subsection{Welfare and Income Equity}

Welfare is a relative economic condition of society. Since the collapse of the imperial system in the Western world through the industrial revolution in Great Britain, scientists' ideas in creating new social orders have emerged, especially in the economic field. Modern economic theory was first born through Adam Smith in 1776 with his work An Inquiry Into the Nature and Causes of Wealth Nations. The main idea is how to create prosperous nation-states without relying on gold and silver but through the management of natural resources. Furthermore, through growing production, economic development will increase, and poverty will automatically disappear. Simon Kuznets provides views on welfare indicators, including; increase in production of both goods and services, which in turn encourages the development of technology in the field of production. Not only that, the government facilitated technological findings in the field of production to be widely developed so that they could be utilized by the community (Darussalam et al., 2019). Through technology, it is hoped that the community will reach a point of optimal productivity to enable prosperity to be realized.

But until now, these ideas and theories have not proven successful, even though they have been perfected by the next generation, namely John Mynard Keynes, through the theory of fiscal policy adopted by many countries after the second world war. In 1976, a macroeconomic theory of monetary policy, which Milton Friedman proposed, emerged, but until now, the global economic situation has become increasingly alarming. Not just periodic crises in the financial sector, but global economic disparities do not show progress. Even world economic observer Joseph E.Stiglitz in his book The Great Divide, Unequal Societies and What We Can Do About Them, which was written published in 2017, reveals the control of wealth in world society by 1 percent of wealthy people (Stiglitz \& Company, t.t.).

One of the failures of the capitalist system stems from the neglect of the distribution system and focuses only on the production system. This can be seen in determining the assumption of per capita income per month. The assumption of per capita income which is used as a measure of the welfare of the people of a country, is not very representative because of the generalization concept of the ratio of gross domestic product to the total population as a reference. At the same time, capitalist countries also assume the criteria of a poor population with an irrational income per capita. For example, Indonesia sets the poverty line at IDR 401,220 per capita per month or the World Bank version of 2 USD per day. At the same time, the income of the richest people reaches tens of billions of rupiahs per month. Based on these facts, it is impossible to distribute welfare in the capitalist system. Ibn Sina argues that a prosperous state will be created if two things are fulfilled: the existence of adequate income and the ability to spend it in a lawful manner, both to fulfill needs and be invested or donated (Ismail, 2012).

Based on the above discussion, philosophically, welfare in Islam is the ability of each individual to generate income to meet needs and the minimum of the income gap. This can be described as follows: Welfare = Adequate Income + Minimum Gap. Referred to as adequate income is direct or indirect income (subsidies or gifts) capable of meeting the needs of dharuriyat and hajiyat.

\subsection{Realizing Welfare with Islamic Economy}

\subsubsection{Welfare Standart}

Determining the standardization of a person's wealth be categorized as a person who is already prosperous is very important. This is necessary to measure the success of the economic system and the strategies implemented. Apart from that, the role of the government as regulator is also very dominant in monitoring the distribution of economic resources and wealth in society. This is actually the economic weakness of capitalism in addressing economic growth that is not accompanied by equitable distribution. The concept of a wealth nation a la capitalism only creates crises and gaps if it is not balanced with an equal distribution that should be done by the government (Chapra, 2005).

Therefore, in Islamic economics, a minimum limit of wealth must be owned by a person to be declared a prosperous person. Ibn Taymiyyah, as quoted by A.A. Islahi emphasized the importance of eliminating poverty. Therefore, every individual must be prosperous and independent from others to fulfill the needs of the world and his religion (Islahi, 1997). Therefore, welfare standardization in the Islamic economy can be formulated as follows:

Fulfillment of individual basic needs, including dharuriyah and basic needs such as; nutritious food, proper clothing, representative housing, and adequate learning opportunities (education) and health facilities. This is as the word of Allah swt:

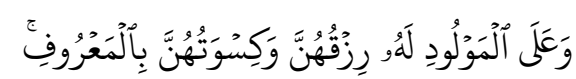

"...And it is the father's duty to feed and clothe mothers in a ma'ruf manner ..." (QS. Al-Baqarah ayat 233).

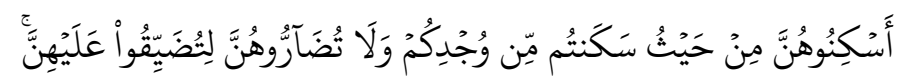

"Place them (wives) where you live according to your ability and do not trouble them to constrict their (hearts) ..." (QS. Ath-Thalaq ayat 6).

Have excess assets of more than 50 dirhams, or the equivalent of 148.75 grams of silver, after meeting the needs of food, clothing, housing, all family and dependents in one house (Zallum, 2015). The excess cash is equivalent to IDR 1.776.000,00 ("Harga Perak dalam Rupiah Indonesia untuk 2021," t.t.).

This provision is based on the hadith of the Prophet:

$$
\text { قيل يا رسول الله: وماذا يعنيه:بة أو ماذا أغناهية قال >خمسون درهما...> }
$$

"He was asked, O Messenger of Allah, what made him a rich man? He said, the wealth of 50 dirhams ..." (HR. an-Nasa'i dan Ahmad). 


\subsubsection{Method to Realize Welfare}

Realizing welfare is a collective task of humans as Khalifah fil ardi, consisting of components of economic actors, namely; individuals, households, business entities, communities, and governments. All components of economic actors have their respective rights, duties and functions that have been regulated by sharia. Each of them is obliged to contribute to production, distribution, and consumption based on the standard of conduct originating from Islam.

Production is an economic activity in producing economic resources in the form of goods, services, and wealth as a medium of exchange that can be used to satisfy needs. The amount of production of goods and services shows the work ethic in society. With the increase in production, wealth distribution will increase and evenly (Kunaifi, 2020a).

Individuals are obliged to support themselves and their families through working activities, cultivating agricultural and plantation land, raising livestock, home industries, and so on. Rasulullah saw motivated his people in the:

$$
\text { طلب الحلال فريضة بعد الفريضة }
$$

"Seeking halal sustenance is one of the obligations among other obligations". (HR. ath-Thabrani).

Community groups or communities contribute to developing the industry of the basic need of the community by building the industry through a partnership contract (syirkah) as said by the Prophet.:

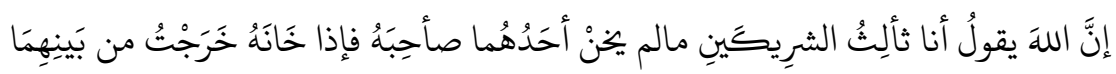

"Indeed, Allah has said, I am a third party for two parties who carry out shirkah as long as one of them does not betray his partner. If one of them betrays his partner, then I will come out of both". (HR. Abu Dawud).

This argument is an allowance for the community to carry out partnership activities or syirkah.

As a regulator of the life of a society, the government is obliged to provide regulations that facilitate community production activities. The regulation in question is in the form of a stimulus in production activities, ease of obtaining permits, light fees, security guarantees, and protection of goods from abroad. The general explanation regarding this matter is as said by the Prophet Muhammad:

$$
\text { فالإمام الذى على الناس راع ومسؤل عن رعيته }
$$

"The leader of humans is the administrator, and he is responsible for the people he takes care of." (HR. al-Bukhari, Muslim, dan Ahmad).

Also mentioned in the kaida of fiqh:

$$
\text { التخفيف والتيسير لا التشديد والتعسير }
$$

"Lighten and make it easier, not make it worse and harder" (al-Qardhawi, 2014).

Apart from the above regulations, Islam explicitly maps production objects that can be handled by the private sector (individuals and companies/communities), the public sector (the interests of the wider community), and the state/government sector. Natural wealth, a standard (public) right, is prohibited from being managed privately because it will cause disputes and injustice. Rasulullah saw said:

$$
\text { المُسلِمونَ شُرَكَاءُ فن ثلاثِ فَ الكلاءِ والمَاءِ والنَارِ }
$$

"Muslims are allied (have equal rights) in three ways; water, fields and fire". (HR. Abu Dawud)

$$
\text { ثلانُ لاَ يُمْنَعْنَ الماءُ والكلاءُ والنارُ }
$$

"There are three things that will never be prohibited (for anyone to have); water, fields and fire". (HR. Ibn Majah) (an-Nabhani, 2012).

Distribution is an activity to convey economic resources to the community so that their needs are met. Therefore, distribution activities are distributing goods produced or providing services to the targeted market and assets or wealth as a medium of exchange. The distribution of goods is also balanced with equal distribution of purchasing power.

Individuals have the responsibility to ensure the adequacy of the family in their dependents. Sharia also commands every human being to be sure of the sustenance of Allah Almighty. Besides, each family member is required to bear the life burden of his heirs or share his inheritance according to sharia. Through inheritance, it guarantees the benefit of the person, family, and society (al-Qardhawi, 2000).

Peoples are collectively ordered to care for their neighbors, for example, not to leave them hungry. Allah Almighty also prohibits hoarding of assets, as stated in Surah at-Taubah verse 34. In addition, entrepreneurs can also empower households by investing in labor-intensive production tools, paying employees appropriately according to the number of services and benefits. The role of community members towards each other in the distribution sector is also carried out by determining a fair ratio in the syirkah that is carried out. Distribution in Islam aims to equalize economic resources. In a capitalist economy, apart from carrying the concept of freedom of ownership, it also means distribution to maximize income or profit. Meanwhile, Islam views distribution as not only to maximize income but also to give property received by someone, which is the right of the recipient. The required distribution of assets to property owners who have met the requirements and conditions equalizes purchasing power to minimize gaps (Sulfinadia, 2015).

Meanwhile, the functions and obligations of the government in distribution activities are to carry out regulation, monitoring, controlling, and solving. The government must ensure that there are no obstacles and bottlenecks in the distribution of economic resources. This command is clearly stated in the word of Allah Almighty: 
"...lest the treasure circulates among the rich only among you..."

As a fiscal policy controller, the government is also obliged to collect as many funds as possible from predetermined sources, especially the exploration of natural resources, public property for benefits and benefits. The profits are then distributed to the public in the form of subsidies and facilities for education, health, public transportation, and so on. The government is also obliged to provide subsidies to people in need, both to cover their autonomous consumption and bankruptcy conditions, local disasters, and conditions that the community does not want (Aziz al-Badri, 2001).

The state has the most important and most effective function in managing the effective distribution of assets. The function of the state in the distribution of assets is known as a fiscal policy. Through fiscal policy, the state has the obligation and authority to collect assets from all sectors, both zakat, infaq, jizyah, and the results of natural wealth management. This adequate source of income is spent to meet all operational needs of the state, including providing subsidies for people with disabilities. This has been written in many articles such as (Saputra, Kunaifi, \& Rosyid, 2021), (Aang Kunaifi, 2021), (Lahjouji \& Rouggani, 2016), (Turmudi, 2019) and others.

Consumption is the activity of utilizing economic resources to meet needs. General regulation of economic activity in Islam is termed al-iqtisha > diyyah, which means simple, balanced, close, or fair.

Philosophical values in Islamic economics regulate people not to be stingy with themselves or avoid enjoying and taking advantage of wealth. If individuals and households carry out consumption activities, the fulfillment of their needs will be hampered and will slow down the wheels of the economy at the macro level. Allah Almighty said:

$$
\text { "And eat clean, good food from what Allah has provided for you ..." (QS. Al-Maidah ayat 88) }
$$

In addition, individuals and households are required to maintain efficiency in consumption and are prioritized to ensure family welfare and sabilillah activities. Maintain the level of consumption from the quality aspect in order to avoid tabdzir or excessive consumption of goods or services that are haram, makruh, or subhat. Consumption must also be maintained so that it is not excessive in terms of quantity or waste (israf). Consumption in an Islamic perspective must meet the basic goal, known as maqashid al-sharia, namely to maintain religion, property, reason, body, and descent (Ilmy, 2019).

The role of business entities in consumption efficiency is in the form of recapitalization. Companies sometimes have many alternative resources that can be used so that they neglect to utilize the resources optimally, in a balanced manner, resulting in the inefficiency of resource users. Finally, there is waste, asset abandonment, and idle assets. Waste or tabdzir that Allah Almighty condemns as He says: "And don't waste (your wealth) wastefully" (TQS. Al-Isra':26). Recapitalization of all assets and resources is carried out in order to avoid waste or inefficiency. Even if there are assets that cannot be utilized, they can be transferred to parties in need, either commercially or as a grant (Kunaifi, 2020b).

The role of the government in public consumption activities is to ensure the availability or safety of stocks of consumer goods and build an efficient culture through law enforcement instruments. This culture can be created through proper regulation and examples from the leaders or officials, as exemplified by Umar bin Abdul Azis, one of the Umayyad caliphs. Through efficient consumption, the country will avoid debt transactions that could endanger security and sovereignty. The independence of a country is the principal capital for the government to establish independent policies for the people's interests, provide subsidies correctly and on target.

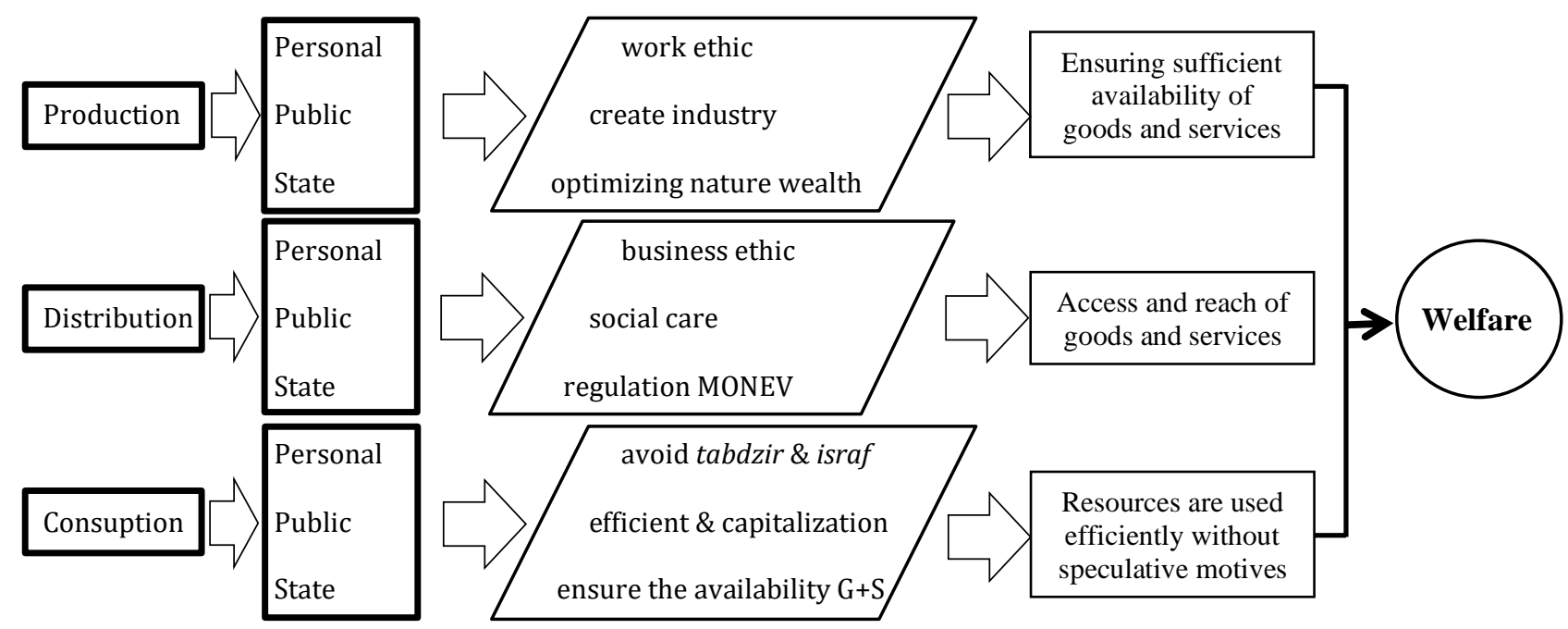

Figure 1. How islamic economics realized welfare

Figure 1 shows the inevitable function of the three components of economic actors, namely individuals, society, and the state. Each of them has a role and function in creating welfare. The three of them must create an interrelation in the form of synergy. In a stricter sense, the three of them must carry out the roles that become their authority. If one of the three neglects it, it will be difficult to achieve equity and prosperity.

\subsubsection{Welfare Authentication in Islamic Economics}

Proving the success of the Islamic economic system in creating prosperity can be traced through the historical facts of the application of the Islamic economic system, both during the time of the Prophet Muhammad, khulafaur Rosyidin, and during the 
caliphate of the Umayyads, Abbasids and Ottomans. In addition, authentication can also be obtained through the opinions of Muslim historians and non-Muslim historians whose credibility has been tested. The Prophet managed the economy of Medina in line with the systems and teachings revealed by Allah. A complete system that does not allow any side of economic activity to escape from regulation. Buying and selling, business systems, agricultural services, skills, and all matters related to financial matters are properly regulated so as not to deviate from a healthy economic order. So that a distinctive system was born, which the Muslims later developed into a tough and shock-resistant monetary law, unlike other fragile and vulnerable systems (Abazhah, 2010). Economic justice and equitable distribution of welfare during the time of the Prophet were undoubtedly created perfectly.

During the khulafur rashidin period, the territory or power of Islam continued to develop so that the mercy of Islamic economic justice had a wider impact. State income has also increased, so financial strength has a significant effect on increasing welfare distribution. During the reign of Abu Bakr, ra., Bayt al-ma> l became the official institution that managed the Khilafah finances with Abu Ubaidah ra., As the head or official of bayt al-ma> l. From the funds collected in bayt al-ma> l, Abu Bakr distributed them to the poor and those who were entitled to receive them. From the treasury of bayt al-ma> l, the Caliph Abu Bakr paid the officials including allowances for himself as Caliph and allocated existing funds for the development of military facilities to strengthen da'wah and fi sabilillah (Jalaluddin al-Suyuthi, 2016). Likewise, during Umar bin Khattab, Uthman bin Affan, and Ali bin Abi Talib, the pro-people's welfare policy continued.

During the Umayyad era, the strengthening of Islamic economic monetary was achieved by manufacturing an Islamic state currency that was printed independently, namely during the caliphate Abdul Malik bin Marwan. Umar bin Abdul Azis was the most spectacular period in creating an even distribution of the people's welfare. In his time, the people's economic facilities and facilities were fulfilled, agricultural productivity increased, and no poverty. This is achieved through a fair subsidy program for the community and orientation to economic development based on growth and social welfare (Ghulam Faizi, 2012).

The government's attention to equitable distribution of social welfare is a commitment that becomes a philosophical truth as said by the Prophet:

$$
\text { الإمَامُ راعِ وَمسئولُ عن زَعيتِه }
$$

"An amir (Imam) of humans is a leader and will be held accountable for his leadership" (HR. Bukhari No.844)

(Fathullah, 2014).

The implementation of the hadith has become the philosophical foundation of the leaders during the era of Islamic rule since the era of the Prophet Muhammad, Khulafaur Rasyidin, Bani Umayyah, Bani Abbasiyah, and Bani Utsmaniyah. ${ }^{2}$ The form of government responsibility to realize this welfare is reflected in the development and fiscal policies implemented. During the Uthmaniyyah Khilafah, for example, policies were structured and systematically carried out (Kunaifi, 2018):

1. Provision of free public services and facilities

2. Accountable selection of government officials

3. Development of recreational facilities, city parks, and urban beauties

4. Firm and just law enforcement

5. The example of the Caliph in simplicity

The historical data above is a one-sided claim from Muslim historians and confirmed by research results from non-Muslim historians. In his book entitled The Story of Civilization, Will Durant mentions: "During the reign of Abdurrahman III, he earned an income of 12,045,000 gold dinars. It is strongly suspected that this figure exceeds the revenues of the governments of the Latin Gregorian countries combined. This large source of income does not come from high taxes, but one of the effects of good governance and the progress of agriculture, industry, and rapid trading activity." ("Barat Mengakui Keagungan Peradaban Di Era Khilafah - AlWa'ie," t.t.).

A history professor from Miami University Oxford, Matthew S Gordon, in his book The Rise of Islam, said that the civilization achieved by Islam in the economy as "growth of regional and trans-regional trade, and of urban manufacturing, produced new level of prosperity across the city landscape "(Kurnia, 2013).

To provide a brief description of the philosophical value of welfare in Islam versus capitalism, it can be seen in Table 4 . Table 4 emphasizes the main weakness of capitalism, which only focuses on production and does not make comprehensive arrangements for the effective distribution of goods and services that fulfill needs.

Table 4. Philosophical characteristics of islamic welfare

\begin{tabular}{llll}
\hline Economic System & Philosophy Base & Method & Authentication \\
\hline Capitalism & $\begin{array}{l}\text { Philosopher } \\
\text { (Human) }\end{array}$ & $\begin{array}{l}\text { The liberalism of ownership and } \\
\text { natural resources management }\end{array}$ & $\begin{array}{l}\text { Creating high productivity } \\
\text { and also the high economic } \\
\text { gap }\end{array}$ \\
Islam & $\begin{array}{l}\text { Revelation and Islamic } \\
\text { Law (Quran and Hadith) }\end{array}$ & $\begin{array}{l}\text { Distribution of ownership. Natural } \\
\text { resources management based on sharia }\end{array}$ & $\begin{array}{l}\text { Creating enough productivity, } \\
\text { but relatively no gap }\end{array}$ \\
\hline
\end{tabular}

\section{CONCLUSION}

Divine values are the principal basis of the aims, means, and policies of Islamic economics. This divine or transcendental value becomes the basis for all economic activity (production, distribution, and consumption) which subsequently becomes the hallmark of the Islamic economic system. Thus, welfare is a human ideal that can be conceptualized and realized through Islamic economics.

Fulfilling the basic needs of individuals and households is the primary indicator of creating prosperity. Therefore, Islamic economics not only focuses on production and growth like capitalist economies, but also regulates in detail the distribution and consumption of economic resources. These rules include rules regarding the roles, functions, rights, and obligations of economic actors, namely individuals, congregations (society), and the government. Resource ownership arrangements are separated between private property, public property, and state property so that economic inequality can be anticipated from the start. The

\footnotetext{
2 The mention of this era is the phases of implementing the Islamic government system as recognized by Imam Jalaluddin and Ash Shalabi in the books they wrote. Although in these phases there was a sultanate (province) that stood out so that it seemed to exist as a separate caliph.
} 
historical fact of the success of the Islamic economy in the welfare of the people is a one-sided claim of Muslim historians and nonMuslim historians who have objectivity and credibility.

\section{ACKNOWLEDGEMENT}

All of the authors in this paper would like to thank all administrators of the Indonesian Muslim Intellectual Association (HILMI) who have organized a conference to initiate and accommodate concepts in solving pandemic problems from the perspective of Islamic civilization. Through this event, this article is here to color the treasures of Islam, especially in the economic field. In particular, we also express our gratitude for the corrections, suggestions, and advice from Dr. Arim Nasim, M.Ak, and Dr. Eka Cahya Prima, M.T, so this paper looks better. And also our highest appreciation for our teachers' ideas and thoughts; Prof. Dr. Ing. Fahmi Amhar, M.Sc, Prof. Dr. Ahmad Zahro, MA, Prof. Dr. Nur Syam, M.Si, and Prof. Dr. Ahmad Imam Mawardi, MA. The data he has provided have inspired this paper. So hopefully, this article will be a good deed for all involved and useful for the people.

\section{References}

Abazhah, N. (2010). Ketika Nabi di Kota; Kisah Sehari-hari Nabi di Madinah, terj. Asy'ari Khatib dari judul asli Fi> Madinah al-Rasul. Jakarta: Zaman.

Abdurrahman, H. (2010). Diskursus Islam Politik dan Spiritual (1 ed.). Bogor: Al-Azhar Press.

al-Qardhawi, Y. (2000). Norma dan Etika Ekonomi Islam (Terjemahan dari Daurul Qiyam wal Akhlaq fi al-Iqtishadi al-Islami). Jakarta: Gema Insani Press.

al-Qardhawi, Y. (2014). 7 Kaidah Utama Fikih Muamalat. Jakarta: Pustaka al-Kautsar.

an-Nabhani, T. (2012). Sistem Ekonomi Islam (Terjemahan dari Nizhamul Islam). Jakarta: HTI Press.

Athoillah, M. A., \& Q-Anees, B. (t.t.). Filsafat Ekonomi Islam. Jakarta: Shahifa.

Aziz al-Badri, A. (2001). Hidup Sejahtera dalam Naungan Islam (Terjemahan dari Al-Islam Dhaminun lil Hajat al-Asasiyah likulli Fardin wa Ya'malu lirafahiyatihi). Jakarta: Gema Insani Press.

Badan Pusat Statistik. (t.t.). Diambil 14 Februari 2021, dari https://www.bps.go.id/pressrelease/2020/07/15/1744/persentasependuduk-miskin-maret-2020-naik-menjadi-9-78-persen.html

Barat Mengakui Keagungan Peradaban di Era Khilafah - Al-Wa'ie. (t.t.). Diambil 16 Februari 2021, dari https://alwaie.id/afkar/barat-mengakui-keagungan-peradaban-di-era-khilafah/

Chapra, U. (2005). Islam dan Pembangunan Ekonomi. Jakarta: Gema Insani.

Darussalam, A. Z., Adilah, A. N., Berlian, B., \& Danial, M. (2019). Konsep Pertumbuhan Ekonomi dan Kesejahteraan dalam Islam. Jurnal Iqtisaduna, 5(2), 264-273. https://doi.org/10.24252/iqtisaduna.v5i2.18998

Davies, G. (2010). History of Money. University of Wales Press.

Fathullah, A. L. (2014). 60 Hadits Sulthaniyah Hadits-Hadits Tentang Penguasa. Bogor: Pustaka Thariqul Izzah.

Ghulam Faizi, H. (2012). Umar bin Abdul Aziz 29 Bulan Mengubah Dunia. cahayasiroh.com: Cahaya Siroh.

Harga Perak dalam Rupiah Indonesia untuk 2021. (t.t.). Diambil 25 April 2021, dari https://www.rupiah365.com/Perak/2021

Ilmy, R. M. (2019). The Concept of Production, Distribution, and Consumption in Islamic Economics. Review of Islamic Economics and Finance (RIEF), 2(1), 38-43. https://doi.org/10.17509/rief.v2i1.17637

Inequality_Income inequality-OECD Data. (t.t.). Diambil 14 Februari 2021, dari TheOECD website: http://data.oecd.org/inequality/income-inequality.htm

Islahi, A. A. (1997). Konsepsi Ekonomi Ibnu Taimiyah (Terjemahan). Surabaya: Bina Ilmu.

Ismail, M. N. (2012). The Islamic Wealth Management: An Analysis from Ibn Sīnā's Perspective. Journal of Islamic Thought and Civilization, 2(1), 19-36.

Jalaluddin al-Suyuthi, I. (2016). Tarikh Khulafa' "terj” Samson Rahman dari kitab asli Tarikhul Khulafa' (4 ed.). Jakarta: Pustaka alKautsar.

Kunaifi, A. (2018). Telaah Kritis Kebijakan Fiskal Perspektif Kaidah Fiqh. Proceedings International Seminar, The 3rd Annual International on Islamic International Education, 3(1), 21.

Kunaifi, A. (2020a). Empowerment Ekonomi Publik Dalam Mengatasi Resesi Dampak Pandemi. Dalam 1: Vol. 1. Perspektif Multidisipliner dalam Pelaksanaan Adaptasi Kebiasaan Baru (1 ed., Vol. 1, hlm. 3-12). Tulungagung: Akademia Pustaka.

Kunaifi, A. (2020b). Panca Re-Si Manajemen Perubahan: Strategi Baru di Era Normal Baru. Dalam 1. Bunga Rampai Kolaborasi Multidisiplin Ilmu dalam Menghadapi Tantangan di Era New Normal (hlm. 95-104). Tulungagung: Akademia Pustaka.

Kunaifi, A. (2021). Quantitative Easing In Overcoming the Crisis: Criticism ofQeinthe Monetary System Of Capitalism. Turkish Journal of Computer and Mathematics Education (TURCOMAT), 12(3), 3703-3714.

Kurnia, R. (2013). Khilafah Sebagai Model Acuan Peradaban Islam. Dipresentasikan pada Jakarta International Conference of Muslim Intelectual, Jakarta.

Lahjouji, H., \& Rouggani, K. (2016). Zakat and Distribution of Wealth on Islamic Economy: Case of Morocco. International Journal of Islamic Economics and Finance Studies, 2(3), 151-160.

Mansur, A. (2013, November). Menjawab Tantangan Bisnis 2013. Dipresentasikan pada Workshop Pengusaha Muslim, Pamekasan.

Muslih, M. (2014). Filsafat Ilmu (Revised). Yogyakarta: Belukar.

Nasim, A. (2018). Sistem dan Politik Ekonomi Islam dalam Mewujudkan Kesejahteraan. Jurnal Kajian Peradaban Islam, 1(1), 8-16. https://doi.org/10.47076/jkpis.v1i1.8

Rivai, V., Nuruddin, A., \& Ananda Arfa, F. (2012). Islamic Business and EconomicEthics (First). Jakarta: Bumi Aksara.

Rochman, T. (2020). Nilai Nilai Instrumental Ekonomi Islam dalam Kesejahteraan masyarakat ditengah Covid 19. ICODEV: Indonesian Community Development Journal, 1(1), 35-47. https://doi.org/10.24090/icodev.v1i1.4259

Saputra, T. A., Kunaifi, A., \& Rosyid, A. (2021). Benarkah Kebijakan Fiskal Islam Efektif Menghadapi Resesi? (Kontekstualisasi Kebijakan Fiskal Sesuai Shariah). Prosiding Seminar STIAMI, 8(1), 1-6.

Stiglitz, J. E., \& Company, W. W. N. (t.t.). The Great Divide: Unequal Societies and What We Can Do About Them. 352.

Suardi, D. (2021). Makna Kesejahteraan dalam Sudut Pandang Ekonomi Islam. Islamic Banking: Jurnal Pemikiran Dan Pengembangan Perbankan Syariah, 6(2), 321-334. https://doi.org/10.36908/isbank.v6i2.180

Sulfinadia, H. (2015). Solusi ekonomi Islam terhadap distribusi harta. Al-Masharif: Jurnal Ilmu Ekonomi Dan Keislaman, 3(1), 5271.

Tafsir, A. (2013). Filsafat Umum (Revised). Bandung: Remaja Rosdakarya.

Turmudi, I. (2019). Kajian Kebijakan Fiskal dan Kebijakan Moneter dalam Islam. An-Nawa: Jurnal Studi Islam, 2(1), 74-90. 
Yusanto, I., \& Yunus, A. (2009). Pengantar Ekonomi Islam. Bogor: Al-Azhar Press.

Zakaria, F. (2011). The Post-American World Release 2.0 Updated and Expanded (2nd ed.). New York, United State of America: W.W.Norton \& Company. Diambil dari www.wwnorton.com

Zallum, A. Q. (2015). Sistem Keuangan Negara Khilafah (Terjemahan dari kitab al-amwal fi daulah khilafah). Jakarta: HTI Press. 